\title{
Preparing More than Number Crunchers: Incorporating Corporate Social Responsibility and Ethics in Graduate Business Programs
}

\author{
Michael D. Cook ${ }^{1}$, Michael Kenneth Holt ${ }^{1,2}$ \& Carmen Reagan ${ }^{2}$ \\ ${ }^{1}$ Grand Canyon University, Phoenix, AZ, USA \\ ${ }^{2}$ Austin Peay State University, Clarksville, TN, USA \\ Correspondence: M. Kenneth Holt, College of Business, Austin Peay State University, Clarksville, TN, USA. Tel: \\ 1-931-221-7075. E-mail: holtm@apsu.edu
}

\author{
Received: October 2, $2014 \quad$ Accepted: October 30, 2014 Online Published: November 26, 2014 \\ doi:10.5539/jms.v4n4p32 URL: http://dx.doi.org/10.5539/jms.v4n4p32
}

\begin{abstract}
CSR has become an area of focus for many companies and business leaders. Few can argue that pursuing business practices that have economic, environmental, and social benefits is not worthwhile. Certainly in the recent aftermath of such publically visible ethical failures as Enron, Lehman Brothers, and BP, many involved in graduate business education have called for the inclusion of CSR principles into their programs' curriculum. This paper explores the need for CSR to be incorporated into graduate business curriculum and looks at how several schools are doing just that. The paper includes a discussion of future research topics and concludes that graduate business programs must increase efforts to include CSR, sustainability, and ethics across the curriculum in order for students to be truly prepared for the demands of the new business world.
\end{abstract}

Keywords: corporate social responsibility, sustainability, ethics, MBA curriculum

\section{Introduction}

One of the more popular subjects in many of today's graduate business programs is corporate social responsibility (CSR). While there are countless ways to describe what CSR entails, the World Business Council for Sustainable Development defined CSR in 2001 as "the continuing commitment by business to behave ethically and contribute to economic developments while improving the quality of life of the workforce and their families as well as the local community and society at large" (Cornelius et al., 2007, p. 119). Certainly in the recent aftermath of such publically visible ethical failures as Enron, Lehman Brothers, and BP, many involved in graduate business education have called for the inclusion of CSR principles into their programs' curriculum. Researchers and administrators continue to debate the role of teaching such subjects as ethics, sustainability, and corporate citizenship as part of the academic program, however (Christensen et al., 2007, p. 348).

Despite some scrutiny with respect to teaching CSR principles, many graduate faculty members enthusiastically support the practice. Dr. Timothy Fort of George Washington University asserts that "in looking at the activities of business school programs, it seems that what was once considered a loony, fringe class is now essential" (2010, p. 737). This desire is not limited to those in academia; corporate leaders have expressed a need for further inclusion of ethics and responsibility as well. The $21^{\text {st }}$ century marketplace has new demands, and in order to stay in step with competitors, many companies "continue to seek the help of business schools in redefining what it means to be socially responsible, and teaching students to have a socially responsible mindset with decision-making skills that look beyond short-term benefits" (Vallario, 2010, p. 52). This is likely in response to an increasingly environmentally and socially aware public. Consumers now consider the ecological impact of a company's production practices before purchasing one of its products. Some shoppers will shun a product if they become aware of a manufacturer employing unfair labor practices. In 2001, a Hill \& Knowlton/Harris Interactive Poll revealed that $79 \%$ of Americans take corporate citizenship into account when deciding whether to buy a particular company's product (Javier, 2005, p. S10). Such statistics reinforce the wisdom in weaving CSR principles throughout the graduate business curriculum, so as to prepare the rising generation of business leaders to meet rising expectations.

\section{Literature Review}

Several of the nation's leading business schools have opted to include CSR as part of their programs of study, 
among them the Haas School of Business at the University of California-Berkeley. Jo Mackness, executive director of the Center for Responsible Business at Haas, claims that "about $40 \%$ of the graduate students come to Berkeley specifically because of its reputation as a premier CSR educational center offering innovative courses" (Vallario, 2010, p. 53). Schools that enthusiastically teach CSR frequently offer such classes, at times dedicating entire courses solely to corporate citizenship and ethics. Notwithstanding the efforts of faculty at Berkeley and other schools with comparable programs, social activist Mark Albion explains that "business schools do not lead best practices; they adapt when students and alumni clamor for more attention to such topics as ethics, corporate social responsibility, and globalization" (Galagan, 2009, p. 27). As corporations increasingly seek to hire recent graduates with both an understanding of CSR initiatives as well as the drive to implement them in the workplace, graduate business programs will continue to expand their offerings in relation to CSR in order to meet the needs of both students and the business community.

Galagan identifies ways in which CSR has permeated the academic curriculum of several programs, stating that "today's MBA program is as likely to cover corporate social responsibility as it is to teach finance and accounting. The standard curriculum used in most business schools now supplements so-called hard subjects with some that could be labeled both soft and green" (2009, p. 26). This trend appears to be substantiated by a 2007 study sponsored by the Center for business Ethics at Bentley College and the Ethics Resource Center in Washington, DC. Researchers surveyed deans or program directors at the top 50 business schools as identified in the Financial Times 2006 rating of global MBA programs. Of the schools that responded, $84 \%$ of the schools required students to take courses that address such topics as CSR, sustainability, and business ethics. Of those schools with such a requirement, $27 \%$ taught CSR, ethics, and sustainability together as a single course. The research team reported that based on their survey findings, "MBA education is increasingly embracing CSR and sustainability along with ethics" (Christensen et al., 2007, p. 348-366).

In 2003, Cowton and Cummins surveyed undergradutate, postgraduate and post experience teaching of business ethics in 105 UK institutions. They found that $58 \%$ of business schools taught business ethics, but it was only a core subject at 18 schools (Cornelius et al, 2007, p. 118). Perhaps this low number is due in part to some critics' perceptions that it is not the place of business schools to teach ethics. Cornelius, Wallace, and Tassabehji note that "Pfeffer and Fong support the role of business schools in the development of intellectual capital for corporations and nations, but argue that business school marketing focuses on enhancement of careers and salary: a position more likely to facilitate careerist ethical egoism than a more normative sense of civic virtue or moral agency within leadership" (2007, p. 119). While some business students may appreciate a program focused solely on skills specifically designed to advance their career in the business field, other students appreciate and seek opportunities to develop their awareness of and proficiency in CSR practices.

Cornelius, Wallace, and Tassabehji conducted a study in 2007 and found that the majority of business education is "provided by lower tier schools that have limited availability of suitably qualified staff", and as such, "the nature of ethics training will remain relatively reactive for the foreseeable future" (p. 133). In order to combat this trend, they exhort business schools to actively engage stockholders and become involved in such areas as "training, research, and community programs that promote and engender CSR and ethics awareness" (p. 133). Benn and Dunphy reinforce the need for improvement in business programs in terms of teaching CSR, asserting in 2009 that many programs "do not adequately prepare graduates to deal with the challenges of sustainability issues in the workplace" (Slater \& Dixon-Fowler, 2010, p. 429). Giacalone \& Thompson also echo this sentiment, claiming MBA programs have a profits-first mentality and "indoctrinate future executives to consider all decisions in economic terms without regard for ethical considerations" (Slater \& Dixon-Fowler, 2010, p. 433).

Slater and Dixon-Fowler conducted a study in 2010, studying the relationship between executives' MBA education and their respective companies' corporate environmental performance (CEP). The CEOs of the S\&P 500 firms in 2004 were surveyed, representing firms from 53 different industries. The research teams compared each firm's KLD rating (used to rate an organization's environmental, social, and governance performance) of CEP with their CEOs' biographical information. The researchers claimed that the results suggest that "CEOs with MBAs have a positive influence on CEP" (Slater \& Dixon-Fowler, 2010, p. 434-437).

\section{Critical Analysis}

Clearly, there are many opinions on the subject of CSR, and experts have documented benefits and concerns when it comes to including CSR principles as part of the graduate level business curriculum. For many graduate faculty members, the choice of whether to teach CSR is made easier by an objective examination of the existing body of research. Empirical research has found links between CSR, return on equity, business image, and performance (Cornelius et al., 2007, p. 117). Even the most profits-focused practitioners could argue teaching 
sound principles that lead to such increases. In fact, Pfeffer and Fong assert that business schools have a responsibility to provide practitioners with training in the basics of ethics. This, in turn, would "ideally lead to an informed workplace and act as a catalyst to stimulate socially and ethically grounded corporate activities and programs" (Cornelius et al., 2007, p. 118). CSR's influence on business ethics cannot be ignored. Cornelius argues that "corporate malfeasance, such as at Enron and Parmalat, would have been avoided by employing and appropriately monitoring reactive business ethics practices and procedures" (p. 118).

Of great concern is the mindset of some MBA students with regard to CSR. A study conducted by Cornell University's Johnson Graduate School of Management suggests that "students in the nation's top MBA programs believe in maximizing profits even more strongly than current executives do." Furthermore, the study found that "students also show less interest than their elders in diversity programs and are more opposed to government action aimed at encouraging responsible corporate behavior" (Kiely, 1997, p. 12). If students are uninterested in areas like CSR, sustainability, and ethics, critics are forced to wonder whether faculty members are conveying the importance of these areas in their courses.

Graduate business programs are designed to teach students sound business principles in a variety of fields, such as economics, accounting, finance, and management. As the business world changes, programs should in turn change along with the market, preparing students for new demands and challenges. Galagan compares business schools to the Detroit automakers, claiming that the same models are offered year after year with just a few embellishments (2009, p. 26). Modern understanding of the environmental impact of resource acquisition has caused many to question methods previously held to be industry standard or even best practices. Failing to address topics of interest to the business community such as CSR and sustainability in the curriculum does not serve students well, as they should be prepared to meet the needs of their future employers.

Giacalone and Thompson contend that business programs have become "organization-centered", and as such, fail to ask students to "confront the factually impossible notions of unlimited growth in a world of limited resources, the questionable consumerist ideology based in materialistic goals, and the ecologically unsound tactics that may bring planetary suicide" (Slater \& Dixon-Fowler, 2010, p. 429). An even stronger criticism of graduate business programs was made by Leavitt in 1989, in which it was claimed that MBA programs "create critters with lopsided brains, icy hearts, and shrunken souls" (Slater \& Dixon-Fowler, 2010, p. 433).

CSR and sustainability have penetrated the modern business world, and in many cases have become a company-wide focus. Despite all the criticism and the inevitable shortcomings of MBA programs, there is still a great deal of optimism in terms of general business direction. For example, Fort claims that "we are at the intellectual vortex of articulating a vision of a free, responsible, virtuous, peaceful world" (2009, p. 738). How can collegiate business educators further this trend toward increased corporate citizenship? Dr. Jose Rivera, president of Sagrado Corazon University in Puerto Rico, believes that it is a matter of recognizing and accepting personal responsibility. He explains that "we had to realize that beyond being an educational institution, we are also an organization that is part of the community. When we realized that, we became aware of the ways we could help the community" (Javier, 2005, p. S10). In terms of the effects of this philosophy on business students, Rivera claims students were taught to be better corporate citizens in the future (p. S10). Business students are quick to learn that they will likely become future leaders in the business world, responsible for increasing productivity and overall profit for their organizations. However, faculty should teach them that in addition to being business leaders, they will also be community leaders and as such, will have a responsibility to the communities of which their companies are a part.

\section{Future Research Possibilities}

While there is a growing body of knowledge with regard to CSR, sustainability, and ethics in business programs, clearly there are opportunities for expanded study. For example, Slater \& Dixon-Fowler suggest that their study on the impact of MBA education on CEO's corporate environmental performance (CEP) leaves room for further inquiry as to the motivation behind companies' decision to pursue CEP and sustainability initiatives. Do business leaders choose to implement CSR practices because they feel they have a moral obligation to do so, or because they believe the practices will lead to improved performance indicators? (Slater \& Dixon-Fowler, 2010, p. 438).

Vallario stated that largest student organization at the Haas School of Business at Berkeley is the Net Impact Club, which is "a nonprofit international organization whose mission is to educate and equip individuals to use the power of business to create a more socially and environmentally sustainable world" (Vallario, 2010, p. 53). Some may rule out the influence of such groups, as they are mostly comprised of idealistic students with little experience in "real world" business environments. An interesting study might follow the career achievements of former members of Net Impact to determine the extent to which they are able to pursue in the working world 
what they strongly advocated during school.

\section{Summary}

CSR has become an area of focus for many companies and business leaders. Few can argue that pursuing business practices that have economic, environmental, and social benefits is not worthwhile. The extent to which businesses have a responsibility to their communities, employees, or the planet will continue to be debated for years to come. However, the prevailing opinion for many years that a business' only responsibility was to generate positive results for its stockholders has come under increased scrutiny. Many business leaders have expressed a desire to do well by doing good, so to speak. Business doesn't have to be crass, cutthroat, and entirely self-serving. Indeed, several executives have come to know the satisfaction of helping the underserved and less fortunate while still maintaining a generous profit margin. The very nature of sustainability with respect to the triple bottom line (economic, social, and environmental) is that a business cannot achieve long term success should any of the three areas is negatively impacted. Graduate business programs must increase efforts to include CSR, sustainability, and ethics across the curriculum in order for students to be truly prepared for the demands of the new business world.

\section{References}

Christensen, L., Peirce, E., Hartman, L., Hoffman, W. W., \& Carrier, J. (2007). Ethics, CSR, and Sustainability education in the Financial Times Top 50 Global Business Schools: Baseline Data and Future Research Directions. Journal of Business Ethics, 73(4), 347-368. http://dx.doi.10.1007/s10551-006-9211-5

Cornelius, N., Wallace, J., \& Tassabehji, R. (2007). An Analysis of Corporate Social Responsibility, Corporate Identity and Ethics Teaching in Business Schools. Journal of Business Ethics, 76(1), 117-135. http://dx.doi.10.1007/s10551-006-9271-6

Fort, T. L. (2010). Business Ethics Quarterly Reflections. Business Ethics Quarterly, 20(4), 736-738. http://dx.doi.10.5840/beq201020445

Galagan, P. (2009). Not Your Father's MBA. T+D, 63(1), 26-29. Retrieved from http://search.proquest.com.ezproxy.lib.apsu.edu/docview/227037485? accountid=8437

Javier, P. (2005). Teaching Corporate Social Responsibility. Caribbean Business, 33(18), S10. Retrieved from http://library.gcu.edu:2048/login?url=http://search.ebscohost.com.library.gcu.edu:2048/login.aspx?direct=tr ue $\& d b=$ th $\& A N=17095343 \&$ site $=$ eds-live \&scope $=$ site

Kiely, T. (1997). Tomorrow's Leaders: The world according to generation X. Harvard Business Review, 75(2), 12-13. Retrieved

from http://go.galegroup.com/ps/i.do?id=GALE\%7CA19698721\&v=2.1\&u=tel_a_apsu\&it=r\&p=AONE\&sw=w \&asid $=561 \mathrm{c} 98323722 \mathrm{ae} 0620 \mathrm{~d} 812 \mathrm{ece} 1 \mathrm{c} 1 \mathrm{fa} 9 \mathrm{e}$

Slater, D. J., \& Dixon-Fowler, H. R. (2010). The Future of the Planet in the Hands of MBAs: An Examination of CEO MBA Education and Corporate Environmental Performance. Academy of Management Learning \& Education, 9(3), 429-441. http://dx.doi.org/10.5465/AMLE.2010.53791825

Vallario, C. (2010). The Role Business Schools Play in Promoting Corporate Social Responsibility. Financial Executive, 26(6), 52-55. $\quad$ Retrieved http://search.proquest.com.ezproxy.lib.apsu.edu/docview/733007513?accountid=8437

\section{Copyrights}

Copyright for this article is retained by the author(s), with first publication rights granted to the journal.

This is an open-access article distributed under the terms and conditions of the Creative Commons Attribution license (http://creativecommons.org/licenses/by/3.0/). 